\title{
SOME PHILOSOPHICAL ASPECTS OF PUBLIC HEALTH WORK.*
}

\author{
By H. MALET, B.A., M.D. \\ President of the Birmingham and Midland Branch of the Incorporated Society \\ of Medical Officers of Health; Medical Officer of Health of \\ Wolverhampton.
}

Is choosing a subject for this address, I felt that it would be unsuitable for me to deal with any technical question in connection with our work, for most of you are better informed on such questions than I, and have better opportunities for working them out. The few details that have attracted my attention are too minute and too insufficiently studied to serve for more than possibly to open a discussion. There are, however, certain general considerations with regard to our work, as to its character, our relation to it, and as to the side-light it throws on some other problems, which are, I think, of sufficient interest for us to dwell on them for a short time. I believe that some of these considerations will be gratifying and stimulating to most of us, and I hope the lessons which practical sanitation teaches in politics and politico-economical morality are startling enough to keep us awake for twenty-five minutes.

First, then, as to the work. It is pre-eminently good work. In spite of time and energy occasionally wasted on some fad to be ultimately disproved, in spite of the element of doubt that hangs about some of our practice, as must necessarily be the case when the science is a growing one, and the art so needed that it cannot wait for the perfection of the science, we do confidently know that the work we do is fruitful and truly useful to our fellow-men. This means for us that we can be happy in our work. It has been truly said that in order that people may be happy in their work three things are needed: they must be fit for it, they must not do too much of it, and they must have a sense of success in it-a sure knowledge that so much work has been fruitfully done. We medical officers of health may, I think, without too much presumption, assume that we are fit for our work-I believe that, except for occasional rushes of over-pressure, the most of us are not overworked - and as we know that our work is fruitful, we have every reason for being happy in it. It is no small matter to be happy in one's work ; far from that, it is, for the present at least, one of the

$$
\text { * Presidential Address, read November, } 1898 .
$$


main objects of existence. This is often lost sight of, because so much of the work done nowadays is either so useless or unpleasant that it is only looked on as a disagreeable means of getting pay, and only endured in the hope of escaping from it by short hours in the present, and by rising out of the work in the future. Both hopes are usually vain, seeing that for one man who rises out of his work ninety-nine remain in it, and for most men their work must, after all, occupy so much of their time that happiness must be very partial if they cannot be happy in their work.

Another very important characteristic of sanitary work as a whole is its disinterestedness. I mean now not merely our share in it, but that of all those concerned, both officials, committees, and legislators. The most of this work is such that those who carry it out are themselves the least benefited by it. Certain general provisions, such as those for pure water and good drainage, affect us all, and so does the direct prevention of epidemic disease, as by disinfection or isolation, for we or our children are thus safeguarded. On the other hand, the mass of the routine work, such as the abatement of nuisances, the work in connection with overcrowding, and foul and unhealthy dwellings, that in connection with factories and workshops, and most of that in connection with unwholesome food, has little or no personal advantage for those who carry it out. Now, all work of this description-useful work done for others-is not only a source of true gratification to those engaged in it, but the fact of being so engaged is itself elevating.

On the subject of politics I know so little that I scarcely hold any opinions at all, and I therefore express myself very diffidently. I do not fully know what are the actual theories of various political parties. Such a pleasant phrase as the "government of the people by the people for the people" is a profound mystery to me, and certain assumptions in connection with what is called "liberty," especially that " of the subject," appear to me to be a sort of mild, but not altogether harmless, insanity. But I know that sanitary science, and indeed all medical science, teach unmistakably and emphatically that the only true liberty for any man is to be shown the right way and to be made to walk therein-if by conviction, so much the better; but if not, then by compulsion. These sciences show that in their domain true welfare is only possible by entrusting the government to those who have the requisite knowledge; that true kindness to the ignorant and foolish person will compel him to act wisely instead of letting him bring trouble on himself and others by his ignorance and folly. Of course, any technical science shows equally well the folly of trusting, for example, a 
popular vote of the ignorant on a technical truth; but sanitary and medical science show it with peculiar force, because of the necessary application of their truths to practice. It is indeed true that there is no entirely fatal person except the dunce, and I am very sure that there is no degree of malice or of original sin half so deadly as the tendency in human nature to have opinions about matters very imperfectly understood. It appears to me that in these days of general diffusion of a little knowledge this tendency has reached a climax. We have had the unedifying spectacle of a Church Congress holding a discussion on vivisection, and we have the affairs of empires daily disposed of at every little debating club in the country. This sort of thing is not of such evident consequence when it only deals with affairs in Egypt or China, but when it concerns such a matter as, for instance, protection from smallpox, its immediate gravity becomes very evident-at least, to us.

It is not improbable that if a General Election were now fought out in this country on the question of compulsory vaccination alone, a majority would be returned against it. It is certain that in consequence of popular sentiment overruling technical knowledge ignorant persons are allowed to submit their children to the terrible risks of small-pox. If we knew that a certain unvaccinated anti-vaccinator (by-the-way, there is no such person) had to attend for a time in the wards of a small-pox hospital, it would be our bounden duty to that man, if we had control over him or were his Government, to vaccinate him by force rather than let him in his folly run the risk he would otherwise do; if not, then we have no right to check a suicide or any other person acting self-destructively through ignorance and folly. If the above illustration be true as regards the anti-vaccinator himself, then it is far more so as regards his children. Whatever the liberty of the subject may demand in the matter, we surely believe that to allow any father to expose his children to a certain risk of small-pox without affording them what we know to be a safe protection is an act of the grossest inhumanity - a direct violation of the supreme moral law of kindness. Now, such a case differs only in degree, not in kind, from that of any so-called conseientious objector. It is evident to us that the true welfare not only of the community, but of each individual, demands that he should be vaccinated and re-vaccinated, and if practical politics in this country render a Government unable to enforce this, then practical politics are so far wrong.

Many other matters in our domain equally illustrate the need of individuals being compelled to act rightly, even though they may object to do so, and instances in which little respect is shown to 
the liberty of the subject to live injuriously for others, or for himself, will occur abundantly to you all. Vaccination, through the failure to enforce it, is at present the most striking example of the need of real government; but there are considerations which may to some weaken its force as such an illustration. Many, fully aware of the need of vaccination, may be so weary of the stupidity and so irritated by the unfair evil imputations of the anti-vaccinators that they might be well inclined to let them go their way. Indeed, if anti-vaccinators could be compelled to provide and pay for their own isolation hospitals and their own unvaccinated doctors and nurses, the properly vaccinated members of the community not having any share in the cost or advantages of such provision, then the temptation would be very strong to let the anti-vaccinators learn their bitter lesson from ghastly experience. There are, however, two reasons why none of us can yield to this temptation. In the first place, we know what unmodified small-pox is, and knowing the horror of it, we can hardly be induced to willingly allow any fellow creature to run the risk of it, however willing in his ignorance to do so. In the second place, the folly of the anti-vaccinator does not concern himself; he is almost invariably vaccinated (his parents having been wiser than he), and according to recent experience he appears to be canny enough to be re-vaccinated when necessary; but we feel it our duty to protect his victims, not only his children, but the simple people led away by him.

(By the way of an illustration of imperative government and small respect for the "liberty of the subject," I commend to your notice the anti-vaccinators' isolation plans and their suggested compulsion of persons who would often be very unwilling to obey them.)

It may, of course, be said that Government has nothing to do with kindness or with making people do rightly, and that it must not restrain an individual's actions unless they affect the community. This may be true, but it is idle in practice. It is of importance to the community that each member should be healthy, otherwise he could not properly contribute his share to the commonweal. In proportion as each individual is better, wiser, and happier, by so much will he be more useful to the community. None of the actions of men are limited to the individual, and the only practical line that can be drawn as to restraining them is the line of right. This is equally evident from another point of view. Morality is ultimately founded on goodwill; the moral action is the action of kindness - it does good to others-therefore the Government, in the interests of the community, should govern by 
the moral law. Government should be a wise, imperative kindness to each citizen, even in the interests of the State. You cannot make people good or wise by legislation, true, nor can you make them healthy, but Government can restrain unhealthy doings and enforce healthy ones, and so with foolish or wicked ones.

Much of the misery which petty philanthropies are vainly endeavouring to relieve in this country to-day is the result of insufficient righteous legislation in the past, and this leads me to the second part of my subject.

Hitherto I have endeavoured to show from the analogy of sanitation the need of real government. I wish now to indicate what share sanitation has had in producing just government.

I must remind you of the very partial and peculiar condition of our legislation of not very many years ago. Violence and robbery and offences against property were classed as crimes, but the innumerable ways in which the opportunities of a complex civilization enable a clever or a rich man to cheat and oppress the less clever or poor were taken no account of. The strong in a civilized community are those who have property and abilities. The tendency of old legislation was to protect the strong against the weak, and not to protect the weak against the strong. Here, again, strangely enough, the liberty of the subject stood in the way of justice and progress. It is strange that the subject should be denied the liberty of using his greater strength of body, or the advantage which the possession of a pistol gives him, for the purpose of robbing his neighbour, but be allowed the liberty of robbing that neighbour by his superior cunning or his possession of capital. Was this a relic of times when the most notable powers were personal strength and the possession of arms-when legislation was justly directed to protect the weak against these? Whatever may have been its origin, the maintenance of such a state of things was no doubt largely due to the same dulness of conscience or of intellect which obtained general acceptance for the earlier dicta of political economy. We can easily see that those who would be influenced by the axiom that the interests of the community are best advanced by each individual looking after his own interests would favour a state of legislation which would sanction their sacrificing all other interests to their own, and would regard as extravagant any truer social ideal. Possibly, too, men were so short-sighted that although they saw that actual deeds of violence would result in the break-up of the community, they failed to see that a nation acting on the principle of "every man for himself and the devil take the hindmost" was a kingdom fatally divided against itself. 
At any rate, it is certain that even advanced Liberals, influenced no doubt by the illusory charms of "liberty," could not tolerate interference with the existing state of things. It is hardly credible that John Bright, in speaking on the subject of adulteration of food in 1872 , could have used these words :

"My own impression with regard to this adulteration is that it arises from the very great, and perhaps inevitable, competition in business; and that to a great extent it is promoted by the ignorance of customers. As the ignorance of customers generally is diminishing, we may hope that before long the adulteration of food may also diminish. The noble lord appears to ask that something more extensive and stringent should be done by Parliament. The fact is, it is vain to attempt by the power of Parliament to penetrate into and to track out evils such as those on which the noble lord has dwelt at such length. It is quite impossible that you should have the oversight of the shops of the country by inspectors, and that you should have persons going into shops to buy sugar, pickles, and Cayenne pepper, to get them analyzed, and then raise complaints against shopkeepers and bring them before the magistrates. If men in their private businesses were to be tracked by Government officers and inspectors every hour of the day, life would not be worth having; and I recommend them to move to another country, where they would not be subject to such annoyance."

In spite of Mr. Bright's objection to protecting the poor ignorant customer from dishonest shopkeepers, the Adulteration of Foods Act of 1872, and subsequently the Sale of Food and Drugs Act of 1875, were passed, and have to a large extent accomplished their purpose, without, I believe, banishing any honest shopkeepers from this so oppressed country.

I have quoted Mr. Bright's remarks to emphasize the state of things then. It is so different now, that many of you may fail to see the magnitude of the change by failing to realize the past. Conditions of trade and work, the relations of employer and employed, of buyer and seller, and of landlord and tenant, were regulated almost solely by the then accepted laws of political economy, such as the law of supply and demand. It was generally felt that for legislation to interfere with these would be as useless, and as absurd, as for it to interfere with the laws of Nature. And yet these laws of political economy were founded on pure selfinterest, regarded as the basis of all human action, and were therefore the direct opposite of the laws of Christianity which are based on goodwill, and are indeed the natural laws of true humanity.

You are all very well aware of what a large and inereasing amount of legislation has been done of late years which more and more disregards the old prejudices, and more and more interferes with what used to be considered vested rights. Much of this legis- 
lation has been inoperative, because of its permissive character; but it is yearly becoming more effective, and that it should have been passed at all is a memorable fact.

To get any accurate knowledge of how each Act was obtained, one would need to know the circumstances under which it was passed, not only as to the then existing Government, but as to the electorate, and the share which the electorate had in stimulating the legislation. Without going into all details, we may safely conclude that some part of all such legislation has been secured by the agitation of those who suffer, and is therefore merely self-protective in motive; that some other part is a sop to Cerberus, and therefore also selfish in its origin; and these two sources may have been especially operative since the later extensions of the franchise. But a little consideration will show that most of what has been done has been due, not to any self-interest of the electorate, or of any concerned in the legislation, but simply to a strong general sense of justice and right. (In some instances those who were benefited were incapable of agitating for themselves, and in others they indignantly resented what was intended for their good.)

Now, the point that I am leading up to in all this, as being of special interest to us, is, that this strong general sense of justice and right has been very frequently, I believe in the great majority of cases, at first aroused by health considerations. It is hardly necessary to refer before you to examples of this. The restrictions as to child labour in mines and factories, nearly all the restrictions as to dangerous or unhealthy trades, are the most obvious illustrationsin fact, nearly all legislation in the direction of ameliorating the condition of the poor and protecting workers has been grounded on the demands of health, from the Factory Act, 1833, the Baths and Washhouses Act of 1846 (which commences, "It being desirable for the health "), to the last Factories and Workshops Act, preservation of health is the fundamental idea. There are two notable exceptions, the Poor Law Acts and the Education Acts.

A recent occurrence rather indicates how readily the public conscience is awakened by a health question as compared with others equally imperative as regards their ethical importance. A strong agitation was made in reference to the alleged iniquitous underpay of eertain women employed in the match manufactories, but the public paid no apparent attention to it. Phosphorus poisoning was alleged to be common, and there was an immediate popular outery. The accuracy of either complaint (both were denied) does not affect the argument-the one aroused no excitement, the other did. 
I believe that the demands of sanitation have been a powerful factor in the national education in righteousness; they have aroused the national conscience to the necessity of doing justice and right, in order to satisfy them; and by so doing they have helped to put justice and right in their true position as the only bases of conduct, national or individual. The foundation of all morality is brotherhood, and brotherly feeling can hardly be better aroused than by caring for our neighbour's health. As a sign of this advance in legislation, we have lately had some (we need much more) ethical Acts interfering with some forms of knavery. Even in political economy the old selfish principles are overthrown, although in actual practice work and trade are only very slowly emancipating themselves from the spirit of selfishness and consequent dishonesty.

But while claiming so very much for our own specialty, it would be very unjust to omit reference to the great national teachers and their influence on public thought and feeling. It is really marvellous, and should be most interesting to us as sanitarians and thinkers, to notice how far Thomas Carlyle was ahead of his times, and earned the title of prophet in more senses than one.

Carlyle's "Past and Present" was first published in 1843. The only sanitary Acts (if they could be called such) preceding that date were the Factory Act of 1833 and the Poor Laws Amendment Act of 1834. The first Report of the Health of Towns Commission did not appear until 1844, and the Public Health Act not until 1848, yet in "Past and Present" we have the following:

"Of Time-Bill, Factory-Bill, and other such Bills, the present Editor has no authority to speak. He knows not-it is for others than he to know-in what specific ways it may be feasible to interfere with legislation between the workers and the master-workers; knows only and sees, what all men are beginning to see, that legislative interference, and interferences not a few are indispensable; that as a lawless anarchy of supply-and-demand, on market wages alone, this province of things cannot longer be left. Nay, interference has begun. There are already factory inspectors, who seem to have no lack of work. Perhaps there might be mine inspectors, too. Might there not be furrow-field inspectors withal, and ascertain for us how on seven-and-sixpence a week a human family does live!

"Again, are not sanitary regulations possible for a Legislature? The old Romans had their Ediles, who would, I think, in direct contravention to supply-and-demand, have rigorously seen rammed up into total abolition many a foul cellar in our Southwarks, Saint Gileses, and dark poison lanes, saying sternly, 'Shall a Roman man dwell there?' The Legislature, at whatever cost of consequences, would have had to answer, 'God forbid!' The Legislature, even as it now is, could order all dingy 
manufacturing towns to cease from their soot and darkness; to let in the blessed sunlight, the blue of heaven, and become clear and clean; to burn their coal smoke, namely, and make flame of it. Baths, free air, a wholesome temperature, ceilings twenty feet high, might be ordained by Act of Parliament in all establishments licensed as mills.

"Every toiling Manchester . . . ought it not . . . to have a hundred acres or so of free green field, with trees on it . . f for its little children to disport in, for its . . . workers to take a breath of twilight air in. . . . And to whatsoever 'vested interest' or such-like stood up, gainsaying merely, 'I shall lose profits,' the willing Legislature would answer, 'Yes; but my sons and daughters will gain health, and life, and a soul.' . . . ' What is to become of our cotton trade?' cried certain spinners, when the Factory Bill was proposed. . . . The humanity of England answered steadfastly, 'Deliver me these rickety perishing souls of infants, and let your cotton trade take its chance. God Himself commands the one thing, not God especially the other thing. We cannot have prosperous cotton trades at the expense of keeping the Devil a partner in them !" "

Contrast those sentences with my former quotation from the practical politician, John Bright, spoken twenty-nine years later than the above was written. The politician says a particular legislative interference is impossible, and protests against it that it would render private business not worth having. That very interference is now being carried out daily in every large town in the land. Carlyle suggests many interferences, most of which now are, and others are about to be. He points out that not even a great cotton trade must weigh as anything against the prevention of a wrong. It would almost appear as if the cloudy atmosphere of political shifts rendered even the most upright man purblind to moral truth.

It is interesting to notice to what a very extreme degree sanitation is driving us in at least one direction. The most advanced of modern moral philosophers have pronounced all usury (that is, any payment for the mere use of a thing as apart from deterioration from use) as ethically wrong, and have especially condemned rent as the worst form of usury. In this opinion they are, of course, in accord with all moralists of all times and nations up to about two or three centuries ago. Whether this view is right or wrong, it is, at least, utterly at variance with the practice followed to-day; it would be regarded as the wildest extravagance by almost all business men. Yet we are drawing very near to it.

The most pressing problem in our large manufacturing towns at present is the housing of the poor. It must, I think, be conceded by all who know the conditions that it is not possible for a town labourer to obtain a really healthy house for any rent which he could be reasonably asked to pay. Much ingenuity has been 
expended in planning houses that would be healthy, and yet cost so little that they would, even at low rentals, pay for the capital expended on them. The nearest approach to a solution is found by building in the country, where land is cheap, and affording cheap tram and rail facilities for getting to and from work. But I know of nothing yet done or suggested which, when the cost of the travelling and the time it occupies are taken into account, can be called a practical scheme. The flats, which in some towns have paid a moderate return for their capital expenditure, are artisans', not labourers', dwellings. We seem, as regards healthy town dwellings for labourers earning eighteen or twenty-one shillings a week, to be in this dilemma: We must allow that such should have healthy homes and surroundings for themselves and families. This can only be obtained for them either by considerably increasing their wages, which would mean an interference with the law of supply and demand as regards the labour market, a heresy not to be dreamt of (as yet), or we must provide them with dwellings at rentals that would not pay. The latter plan practically amounts to increasing their wages at the cost of the community, and admits that for them, in part at least, the usury of rent is wrong.

We may follow the lines of thought indicated above to very extreme conclusions. Our improved ideas of what is really necessary for that perfect health which it will be granted is due to each individual who does his share in the world's work will lead us very far. Due air-space and sunlight outside, proper living and sleeping room, shelter, warmth, and ventilation, bathing, washing, and cooking facilities-these, surely, are necessary things, and the due of each citizen. If these are to be for all, then the conditions of modern social and industrial life, that at present render them impossible, will need very close inquiry. Our own professional duties, however, only lie in pointing out fearlessly and honestly those needs which must be earliest satisfied. This we have done in the past, and we are not likely to fail to do so in the future.

Benefits of Notification.-Dr. Woodforde, Medical Officer of Health of the Berks Combined Sanitary District, in his Annual Report for 1897, calls attention to the marked difference in the mortality from non-notified disease prevailing in those divisions of his district which have not adopted the Notification Act as compared with those where notification is in force. Thus in the notifying divisions the mortality from the notifiable diseases was $3 \cdot 76$ per 10,000 , in the non-notifying 12.30; whilst that from non-notifiable disease was 6.22 in the former, and 9.90 in the latter. The total mortality from all zymotic diseases, including erysipelas, was 9.96 in the notifying and 22.22 in the nonnotifying. 